\title{
GPS-GIS based Soil Fertility Maps of Bhudargad Tehsil of Kolhapur District (M.S.), India
}

\author{
B. Ushasri* and C. Mukesh Kumar \\ Division of Soil Science and Agricultural Chemistry, Mahatma Phule Krishi Vidyapeeth, \\ College of Agriculture, Kolhapur-416004, India \\ *Corresponding author
}

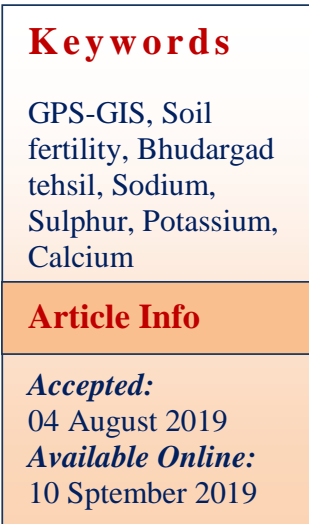

\section{Introduction}

The recent technologies like GPS and GIS thus have much to offer for preparing soil fertility maps. Global positioning system (GPS) is a space based navigation and
The study was carried out to know the fertility status of major nutrients in soils of Bhudargad tehsil, Kolhapur district by using GPS-GIS technology and to correlate soil properties with the available nutrients and to evaluate the fertility index of Bhudargad tehsil. The $\mathrm{pH}$ of soils of Bhudargad tehsil varied from 5.5 to 8.0, most of the soils were moderately acidic (50.67\%) while EC of the soils varied from 0.02 to $1.48 \mathrm{dS} \mathrm{m}^{-1}$, and the values were normal. The calcium carbonate content of soils of Bhudargad tehsil varied from 0.50 to 2.80 per cent. Organic carbon content varied from 0.26 to 1.32 per cent and categorized as very high $(6.67 \%)$, high $(33.3 \%)$, moderately high $(40 \%)$, moderate $(13.33 \%)$ and low $(6.67 \%)$. The available nitrogen, phosphorus and potassium in soils of Bhudargad tehsil ranged from 141.30 to $348.10,7.16$ to 28.00 and 100.20 to $300.00 \mathrm{Kg}$ ha1 , respectively. The soils of were low (57.33\%) in available - nitrogen, low (17.33\%) to moderately high $(42.67 \%)$ in available phosphorus and moderately high $(51.33 \%)$ in available potassium. The exchangeable calcium and magnesium ranged from 6.50 to 48.50 and 1.0 to $19.50 \mathrm{cmol}(\mathrm{p}+) \mathrm{Kg}^{-1}$, respectively. The exchangeable sodium ranged from 0.21 to $2.00 \mathrm{cmol}(\mathrm{p}+) \mathrm{Kg}^{-1}$. The available sulphur varied from 5.14 to $14.97 \mathrm{mg} \mathrm{Kg} \mathrm{Kg}^{-1}$ respectively, and 66 per cent soil samples were in very low category. The $\mathrm{pH}$ was significantly and positively correlated with potassium, calcium and magnesium. The EC was significantly and positively correlated with potassium and calcium. The organic carbon was significantly correlated with nitrogen, copper. Calcium carbonate eq. was significantly correlated with available potassium, calcium and magnesium. The fertility indices of soils of Bhudargad tehsil for organic carbon, available nitrogen, phosphorus and potassium were medium (2.10), low (1.21), low (1.62) and medium (1.94), respectively. 
querying and displaying geographical data (Chang, 2002). Once the soil fertility maps are created, it is possible to transform the information about the fertility status of the area, such maps provide site - specific recommendation, validation for soil fertility over the following years. GPS-GIS are advanced tool for studying on site specific nutrient management which can be efficiently used for monitoring soil fertility status and useful for ensuring balanced fertilization to crops. This tool is useful for systematic study of nutrients including assessment of major, secondary and micronutrient status of soil with delineation of areas of nutrient deficiency or sufficiency.

\section{Materials and Methods}

Bhudargad tehsil of Kolhapur district was selected to assess the soil macro and micro nutrient status and delineate the fertility map, 66 villages were selected randomly in such a way that it covers the whole area of the tehsil. One hundred and fifty representative soil samples were collected from sixty six villages of Bhudargad tehsil along with GPS reading.

Collection and Processing of Soil Samples

Sixty-six villages from Bhudargad tehsil were selected for sampling keeping in mind to avoid overcrowding of sampling site on GPS based soil fertility map. Geo-referenced surface $(0-22.5) \mathrm{cm}$ soil samples from each selected villages representing different soils were collected. The latitude and longitude of sampling sites were recorded with the help of differential Global Positioning system with detailed observation on cropping pattern and fertilizer use. The soil samples were collected with the help of wooden peg. The samples were air dried and ground using wooden mortar and pestle and passed through 2.0 and $0.5 \mathrm{~mm}$ sieves. The sieved soil samples were stored in cloth bags with proper labeling for subsequent analysis. The soils were analyzed for different parameters.
The $\mathrm{pH}$ was measured by in 1:2.5 soil water suspension using glass electrode $\mathrm{pH}$ meter and EC $\left(\mathrm{dS}^{-1} \mathrm{~m}\right)$ was measured in the supernatant solution of 1:2.5 soil water suspension using conductivity meter (Jackson, 1973). Organic carbon by wet oxidation method (Nelson and Sommers, 1982). Available Nitrogen was estimated by alkaline permanganate method of Subbiah and Asija (1956) available phosphorus was extracted with $0.5 \quad M$ $\mathrm{NaHCO}_{3}$ solution buffered at $\mathrm{pH}-8.5$ Watanabe and Olsen (1965) and Bray I $0.03 \mathrm{~N}$ ammonium fluoride at pH-3.5 (Bray and Kurtz, 1945). Available Potassium was estimated by shaking the requisite amount of soil sample with $1 N$ neutral ammonium Acetate solution at $\mathrm{pH}-7.0$ (1:5 soil water ratio), (Knudsen and Peterson, 1982). Available and Sulphur was estimated by turbidimetry with calcium chloride extractable (Williams and Steinbergs, 1959). The $\mathrm{CaCO}_{3}$ $\%$ by Rapid titration method (Piper, 1966) and Exchangeable $\mathrm{Ca}$ and $\mathrm{Mg}$ by Versenate titration method (Page et al., 1982).

\section{Results and Discussion}

The result of the investigation carried out during the year 2015-2016 with the view to study the GPS-GIS based fertility status of soils in Bhudargad tehsil are presented below (Fig. 1-11)

\section{Nutrient status of soils of Bhudargad tehsil}

The soil samples collected from Bhudargad tehsil were analyzed by adopting standard procedure and the data pertaining to different parameters was categorized as per the six tier rating. The data pertaining to $\mathrm{pH}$, Electrical conductivity, Calcium carbonate, and Organic carbon, available $\mathrm{N}, \mathrm{P}$ and $\mathrm{K}$ are presented in Table 1 and 2.

\section{Soil reaction $(\mathrm{pH})$}

The $\mathrm{pH}$ of the 150 soil samples ranged from 5.50 to 8.00. Among the soil samples tested, 
50.67 per cent were moderately acidic, 26 per cent were slightly acidic, 23.33 per cent were slightly alkaline. The high rainfall and leaching of bases like $\mathrm{Ca}, \mathrm{Mg}, \mathrm{Na}, \mathrm{K}$ was the major factor contributed to the increase in acidity in these soils.

Similar nature of observation for soil $\mathrm{pH}$ was also recorded by Sannappa and Manjunath (2013) in soils of Western Ghats of Karnataka, India.

\section{Electrical Conductivity (EC)}

The EC ranged from 0.02 to $1.48 \mathrm{dS} \mathrm{m}^{-1}$ which indicates that most of the soils (96 per cent) were non saline in nature and are suitable for good plant growth remaining 4 per cent soil samples come under poor seed emergence category, due to accumulation of soluble salts on the soil surface and carbonates of $\mathrm{Ca}^{++}$and $\mathrm{Mg}^{++}$might have increased to EC more than 1 $\mathrm{dS} \mathrm{m}^{-1}$. Similar results were reported by Mandavgade et al., (2015) for the soils of Jintur, Selu and Pathri tehsils of Parbhani district, Maharashtra.

The lower values of electrical conductivity might be due to leaching of salts from soil profile under high rainfall and undulating topographic nature.

\section{Per cent calcium carbonate equivalent content}

The per cent calcium carbonate equivalent content of soils ranged from 0.50-2.80 indicating barely to moderately calcareous. Majority area (61.33 per cent) of soils was slightly calcareous. In general the per cent equivalent $\mathrm{CaCO}_{3}$ content was less than $5 \%$, hence soils are very good for cultivation of cereals, pulses and fruit crops.

Similar nature of observation for $\mathrm{CaCO}_{3}$ in soil series of Kolhapur district was reported by
Patil (2011). The content of $\mathrm{CaCO}_{3}$ increased from escarpment towards the foot of hill, gentle sloping of land basin and flat land topography. This might be due to leaching of soluble calcium from hill slopes towards basin area.

\section{Organic carbon}

The organic carbon content ranged from low 0.26 (per cent) to very high (1.32 per cent) with a mean value of 0.74 per cent (moderately high). About 6.67 per cent, 13.33 per cent, 40 per cent, 33 per cent and 6.67 per cent soil samples were under low, moderate, moderately high, high and very high respectively.

Similar results were reported by Jadhav (2014) for Kagal Tehsil of Kolhapur district.

The low and moderate organic carbon content might be due to low input of FYM, crop residues, coarse textured soil nature and high temperatures prevailing during the summer which favours for high rate of decomposition of organic matter in soil. The mean value indicates may be moderately high organic carbon content due to cultivation of field crops, use of organic manures and fertilizers in that particular area (Telele et al., 1992).

\section{Available N}

The available nitrogen was low in majority samples of the study area (57.33 Per cent), this might be due to high rainfall and undulating topography that leads to loss of nitrates by leaching. This variation in $\mathrm{N}$ content might be related to soil management practices, application of organic manures and fertilizers to previous crop.

Similar results were reported by Pulkeshi et al., (2012) in Mantagani village under transition zone of Karnataka. 


\section{Available phosphorus}

The available phosphorus content was moderately high in majority of soils (42.67 Per cent) of the tehsil but it was moderate (40 Per cent) and low (17.33 Per cent) in others. The red lateritic soils showed low available phosphorus which might be due to low organic matter, higher free iron oxide content and acidic soil reaction, and formation of insoluble tri calcium phosphates under alkaline conditions. The similar trend of available phosphorus was reported by Katariya (2011) in soils of the water management project- Block A, central campus, MPKV, Rahuri.

Table.1 pH, EC and $\mathrm{CaCO}_{3}$ content in soils Bhudargad tehsil

\begin{tabular}{|c|c|c|c|}
\hline Particular & $\underset{(1: 2.5)}{p H}$ & $\begin{array}{c}\mathrm{EC}\left(\mathrm{dS} \mathrm{m}^{-1}\right) \\
(1: 2.5)\end{array}$ & $\% \mathrm{CaCO}_{3}$ eq. \\
\hline Mean & 6.60 & 0.27 & 1.61 \\
\hline Range & $5.50-8.00$ & $0.02-1.48$ & $0.5-2.8$ \\
\hline \multirow{5}{*}{ Category } & \multirow[t]{2}{*}{$\begin{array}{l}\text { Moderately acidic } \\
76(50.67 \%)\end{array}$} & \multirow[t]{2}{*}{$\begin{array}{l}\text { Normal } \\
144(96 \%)\end{array}$} & $\begin{array}{c}\text { Barely } \\
\text { calcareous } \\
16(10.67 \%)\end{array}$ \\
\hline & & & Slightly calcareous \\
\hline & \multirow{2}{*}{$\begin{array}{c}\text { Slightly acidic } \\
39(26 \%)\end{array}$} & \multirow{3}{*}{$\begin{array}{c}\text { Poor seed } \\
\text { emergence } \\
6(4 \%)\end{array}$} & $92(61.33 \%)$ \\
\hline & & & Moderately \\
\hline & $\begin{array}{l}\text { Slightly alkaline } \\
35(23.33 \%)\end{array}$ & & $\begin{array}{c}\text { Calcareous } \\
42(28 \%)\end{array}$ \\
\hline
\end{tabular}

Total no. of soil samples-150, figures in parenthesis indicates percentage.

Table.2 Organic carbon and available nitrogen, phosphorus, potassium and sulphur content in soils of Bhudargad tehsil

\begin{tabular}{|c|c|c|c|c|c|}
\hline \multirow{2}{*}{ Particular } & $\begin{array}{c}\text { Organic } \\
\text { carbon (\%) }\end{array}$ & \multicolumn{4}{|c|}{ Available nutrients $\left(\mathbf{k g ~ h a}^{-\mathbf{1}}\right)$} \\
\cline { 3 - 6 } & & $\mathbf{N}$ & $\mathbf{P}$ & $\mathbf{K}$ & $\mathbf{S}$ \\
\hline Mean & 0.74 & 268.27 & 19.52 & 225.30 & 9.01 \\
\hline Range & $0.26-1.32$ & $141.30-348.10$ & $7.16-28.00$ & $100.20-300.00$ & $5.14-14.97$ \\
\hline Very low & - & - & - & - & - \\
\hline Low & $10(6.67 \%)$ & $86(57.33 \%)$ & $26(17.33 \%)$ & $23(15.33 \%)$ & $99(66 \%)$ \\
\hline Moderate & $20(13.33 \%)$ & $64(42.67 \%)$ & $60(40 \%)$ & $10(6.67 \%)$ & $51(34 \%)$ \\
\hline $\begin{array}{c}\text { Moderately } \\
\text { high }\end{array}$ & $60(40 \%)$ & - & $64(42.67 \%)$ & $77(51.33 \%)$ & - \\
\hline High & $50(33.3 \%)$ & - & - & $40(26.67 \%)$ & - \\
\hline Very high & $10(6.67 \%)$ & - & - & - & - \\
\hline
\end{tabular}

Total No. of soil samples-150, figures in parenthesis indicates percentage. 
Fig.1 Location map of study area

Fig.2 pH of Bhudargad tehsil
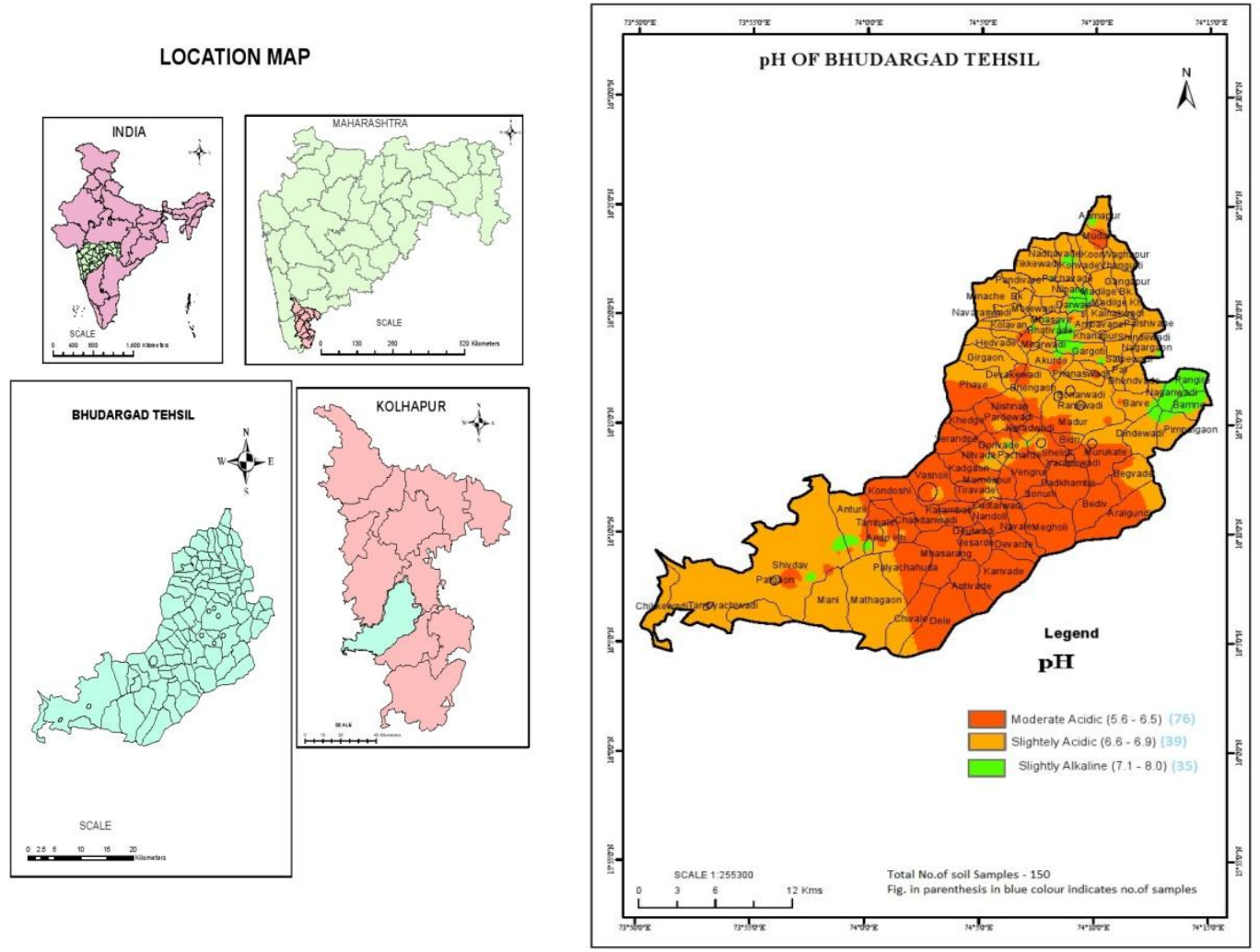

Fig.3 EC of Bhudargad tehsil

Fig. $4 \mathrm{CaCO}_{3}$ content of Bhudargad tehsil
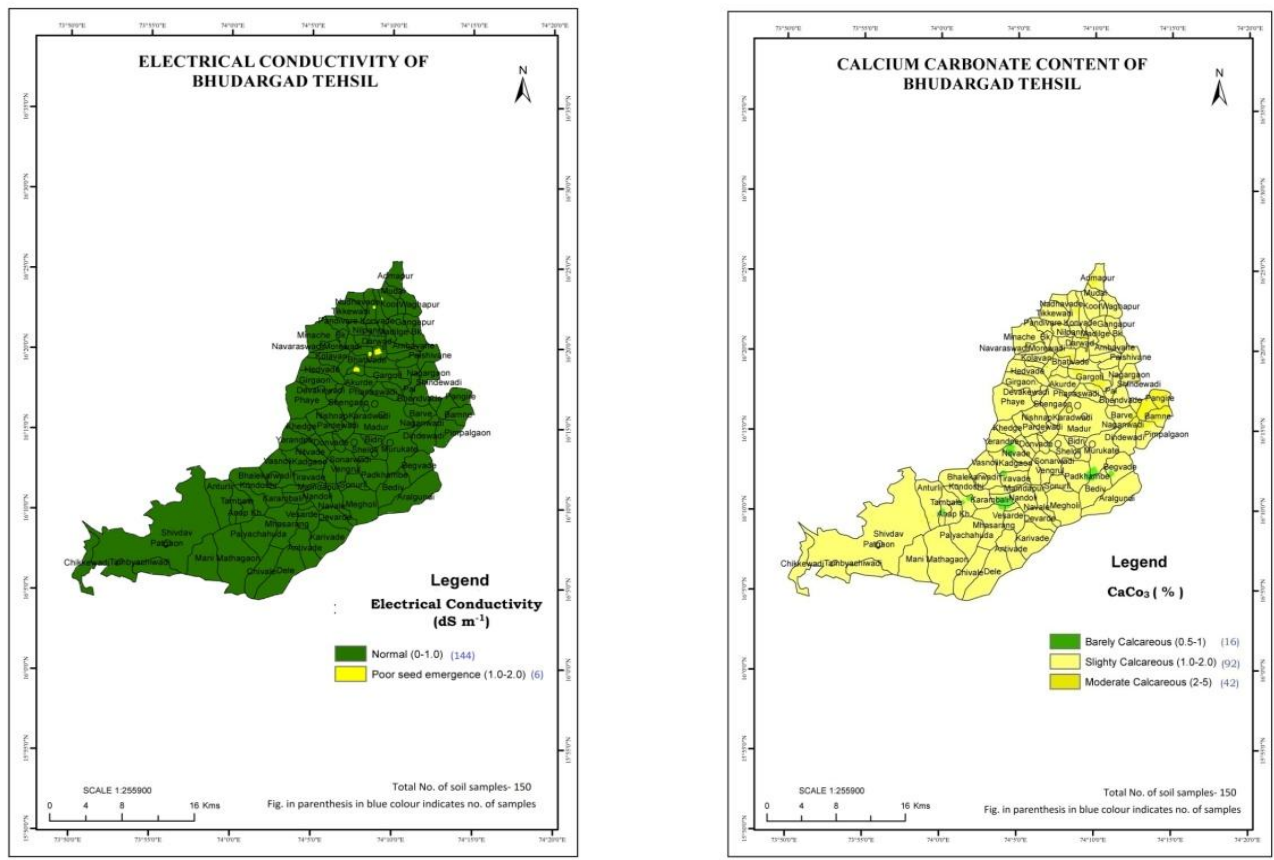
Fig.5 OC of Bhudargad tehsil

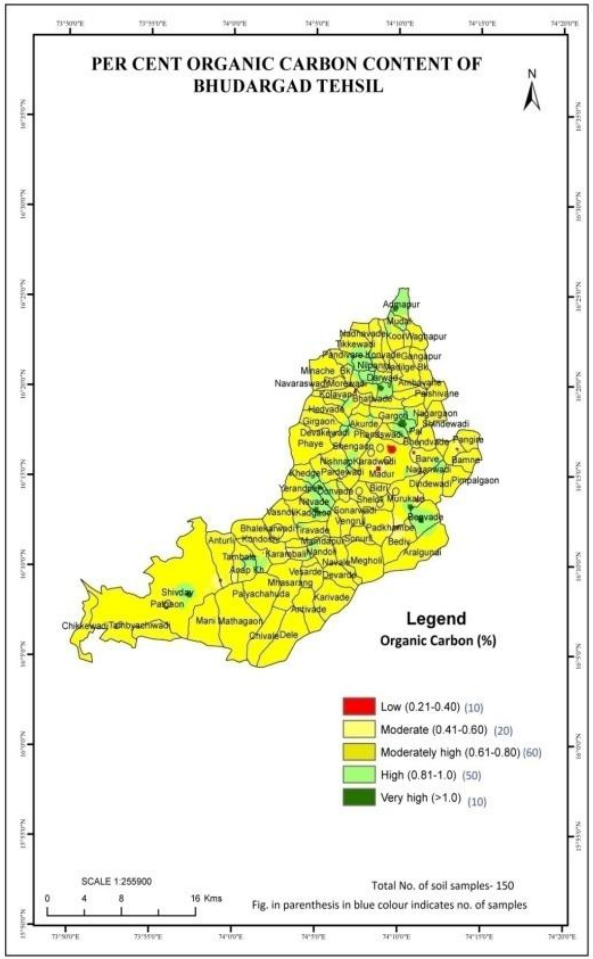

Fig.6 Avail. N of Bhudargad tehsil

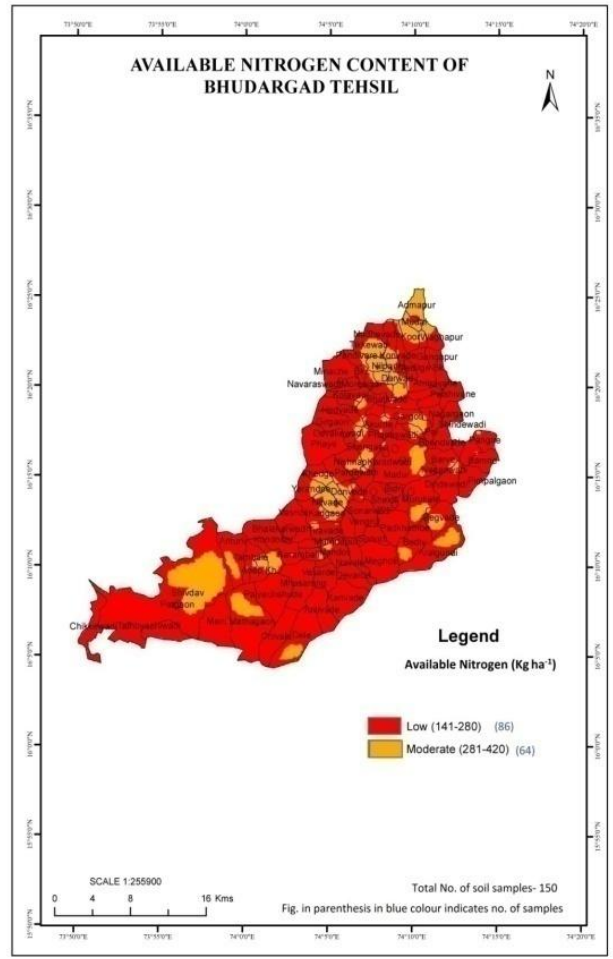

Fig.7 Available P of Bhudargad tehsil

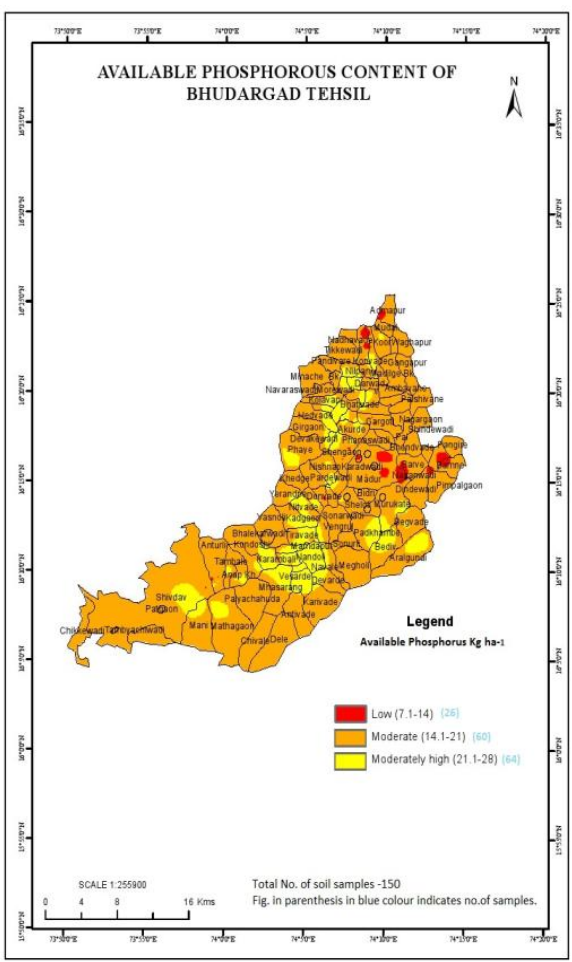

Fig.8 Avail. K of Bhudargad tehsil

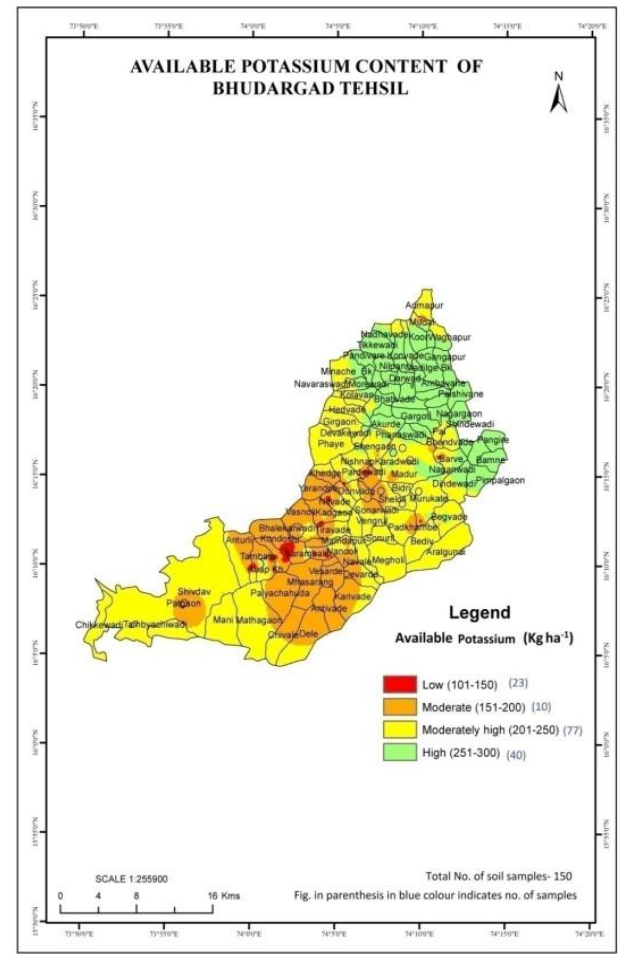


Fig.9 Available $\mathrm{S}$ of Bhudargad tehsil

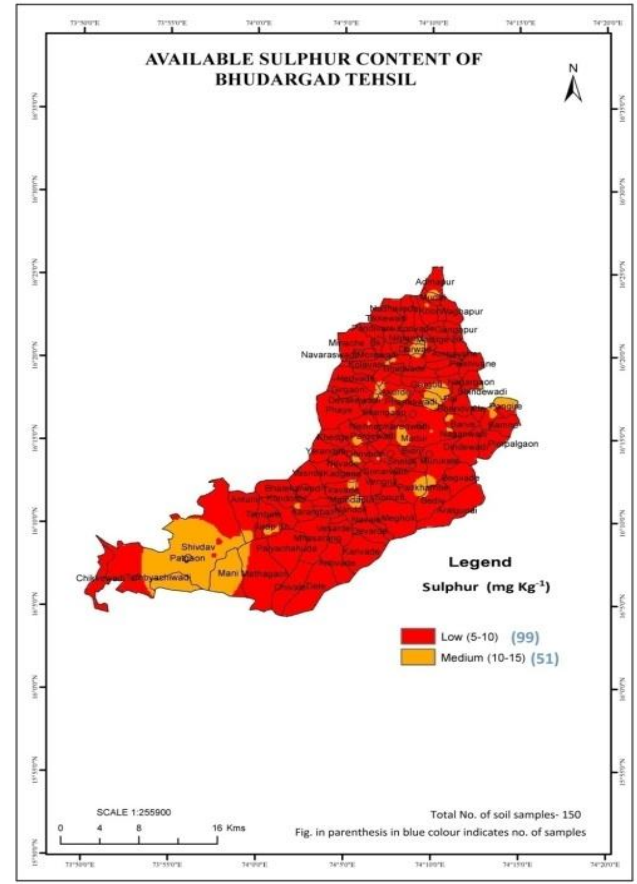

Fig.10 Ca content in Bhudargad tehsil

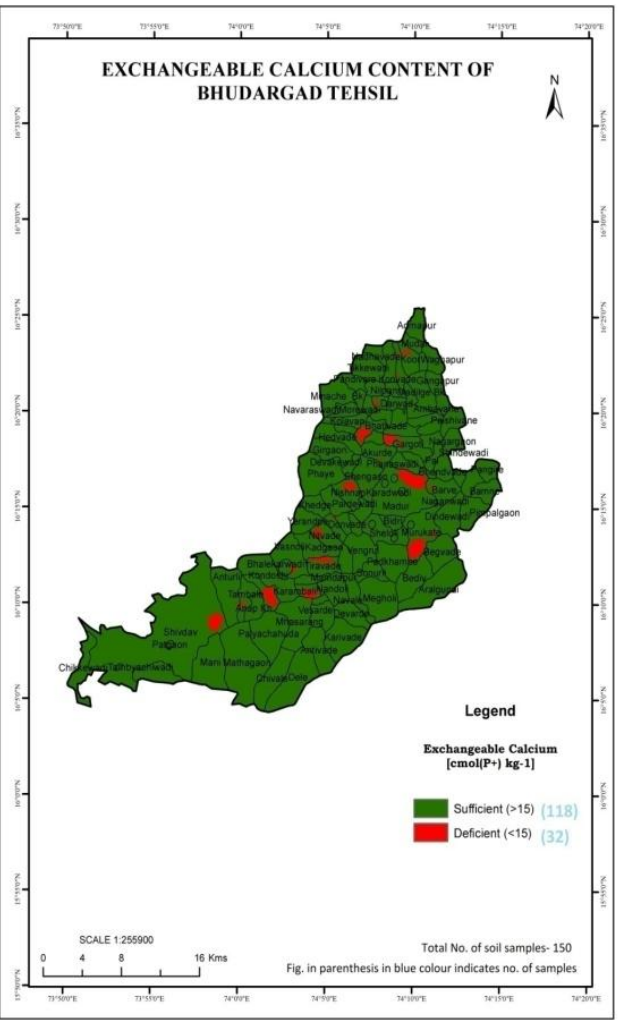

Fig.11 Mg content in Bhudargad tehsil

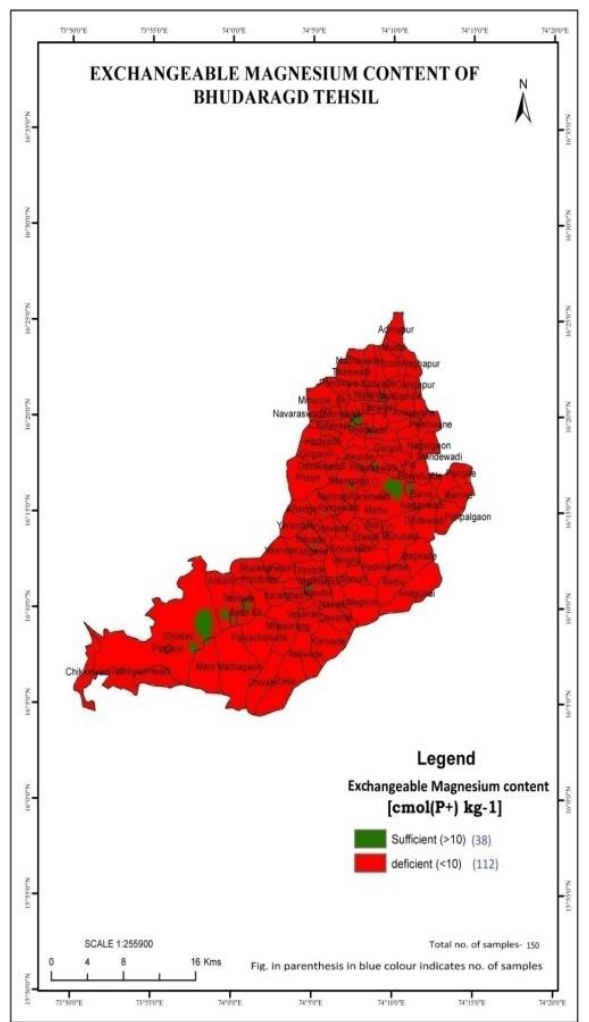




\section{Available K}

The available potassium in the soils ranged from 100.20 to $300.00 \mathrm{~kg} \mathrm{ha}^{-1}$ showing low to high with a mean value of $225.0 \mathrm{~kg} \mathrm{ha}^{-1}$ (moderately high). Out of soil samples collected 15.33 per cent, 6.67 per cent , 51.33 per cent and 26.67 per cent were low, moderate, moderately high and high in available $\mathrm{K}$.

The available potassium content of major portion of the study area was moderately high, might be due to predominance of $\mathrm{K}$ rich micaceous and feldspar minerals in parent material (Pulkeshi et al., 2012). Similar results were also recorded by Sudharani et al., (2013) in rice soils of Vishakapatnam district, Andhra Pradesh.

\section{Available sulphur}

The available sulphur is ranged from 5.14 to $14.97 \mathrm{mg} \mathrm{kg}^{-1}$ i.e., low to moderate with a mean value of $9.01 \mathrm{mg} \mathrm{kg}^{-1}$. About 66 per cent soil samples were low and 34 per cent samples were moderate. The low sulphur content in soils might be due to coarse textured sandy soils, leaching losses due to undulating topography and high rainfall and use of high analysis fertilizers, which are devoid of sulphur.

\section{Exchangeable calcium}

The exchangeable calcium ranged from 6.50 to $48.50\left[\mathrm{cmol}\left(\mathrm{p}^{+}\right) \mathrm{kg}^{-1}\right]$ with a mean value of $22.26\left[\mathrm{cmol}\left(\mathrm{p}^{+}\right) \mathrm{kg}^{-1}\right]$. Out of all the samples collected, 78.67 per cent were sufficient and 21.33 per cent samples were deficient, as the critical limit of available calcium is 15.0 [cmol $\left(\mathrm{p}^{+}\right) \mathrm{kg}^{-1}$ ] (Durgude, 1999).

\section{Exchangeable Magnesium}

The available magnesium ranged from 1.00 to $19.50\left[\mathrm{cmol}\left(\mathrm{p}^{+}\right) \mathrm{kg}^{-1}\right]$ with a mean value of $6.72\left[\mathrm{cmol}\left(\mathrm{p}^{+}\right) \mathrm{kg}^{-1}\right]$. Out of all soil samples, 25.33 per cent were sufficient, while 74.67 per cent were deficient, as the critical limit of exchangeable magnesium is $10\left[\mathrm{cmol}\left(\mathrm{P}^{+}\right) \mathrm{kg}^{1}\right]$ (Durgude,1999).The deficiency of magnesium might be due to the coarse textured soils and leaching losses due to heavy irrigation of some soils. Similar trend of results were observed by Mandal and Sharma (2005) in soils of Nagpur district, (Maharashtra).

From the study, it can be concluded that, the soils of the Bhudargad tehsil were found to be moderately acidic to slightly alkaline in reaction, normal in salt content indicating that the soils are free from salinity, low to high in organic carbon content and non-calcareous to slightly calcareous in per cent calcium carbonate equivalent content. Soils of tehsil were low to moderate in available nitrogen and that indicates nitrogen is the major limiting nutrient in the soils and also found majority samples were high $(42.67 \%)$ in available phosphorus where as low $(15.33 \%)$ to high $(26.67 \%)$ in available potassium content. The soils were low $(66 \%)$ to moderate $(34 \%)$ in available sulphur and 21.33 and and 74.67 per cent soil samples found deficient in exchangeable calcium and in exchangeable magnesium content respectively. The maps generated under the study will be useful for generating homogenous units and guiding the farmers to decide the amount and kind of macronutrients to be applied for optimizing economic returns. The geo-referenced sampling sites can be revisited with the help of GPS, which helps in monitoring the changes in the status of nutrients over a period of time, which otherwise is not possible by traditional methods of sampling.

\section{References}

Bray, R. H. and Kurtz, L. T. 1945, Determination of total, organic, and available forms of phosphorus in soils. 
Soil Science, 59: 39-45.

Chang, K. 2002. Introduction to Geographic Information Systems. Tata Mc-Graw Hill Publishing Co., New Delhi, India, 348

Durgude, A.G. 1999. Morphology, Characterization, Classification and Mapping of salt affected soils of central campus, research farms, MPKV., Rahuri. Ph.D. thesis submitted to MPKV, Rahuri (M.S.).

French, G. T. 1996. Understanding the GPS. GeoResearch pub-lishers, Woodmont Avenue, USA. 255.

Jackson, M.L. 1973. Soil Chemical Analysis. Prentice Hall of India Pvt. Ltd., New Delhi,:256-260.

Jadhav, R. D. 2014. GPS-GIS based soil fertility maps of 'Kagal' Tehsil of Kolhapur district (M. S.) M. Sc. (Agri.) Thesis, M. P. K. V., Rahuri.

Kanwar, J.S. 1976 in soil fertility- Theory and practical. Indian Council of Agriculture Research, New Delhi, 202.

Katariya, P. 2011. Characterization and classification of soils of water management project, MPKV, Rahuri. M.Sc. (Agri) Thesis, Mahatma Phule Krishi Vidyapeeth Rahuri (Maharashtra) India.

Knudsen, D.A. and Peterson, G.A. 1982. Lithium, Sodium and Potassium, 225246. In A. L. Page (ed). Method soil analysis Agronomy monogram No. 9. Am, Soc. Agron Incl. Soil Sci. Soc. Am. Publ., Madison, Wisconsin, USA.

Mandavgade, R.R., Waikar, S.L., Dhamak, A.L. and Patil, V.D. 2015. Evaluation of micronutrient status of soils and their correlation with some chemical properties of soils of northern tehsils (Jintur, Selu and Pathri) of Parbhani district. IOSR J. Agril. and Vet. Sci. 8(2): 38-41.

Mandal, A.K. and Sharma, R.C. 2005. Computerized data base of salt-affected soils in peninsular India using geographic information system. $J$. Indian Soc. Soil Sci. 58(1):105-116.

Nelson, D.W. and Sommer, L.E. 1982. Total carbon and organic matter. In methods of soil analysis, Part - 2, Page, A.L.(Ed.) Am. Soc. Agron. Inc. Soil Sci. Soc. Am. Inc. Madison, Wise. USA : 539-577.

Page, A.L. (Ed). 1982. Methods of soil analysis Agronomy Monograph No-9. Pt.2. American Soc. of Agron. Inc. Soil Sci Soc. of Amer. Inc. Publ. Medison, Wisconsin, USA.

Patil, S.S. 2011. Studies on soil Morphological, Chemical and Physical Properties of important soil series of Kolhapur district. M.Sc. (Agri.) Thesis, MPKV, Rahuri.

Piper, C.S. 1966. Soil and plant analysis, Hans publishers Bombay, 135-136.

Pulkeshi, H.B.P., Patil, P.L, Dasog, G.S, Bidari, B. I. and Mansur, C.P. 2012. Mapping of nutrient status by geographic information system in Mantagani village under northen transition zone of Karnataka. Karnataka J. Agric. Sci., 25(3): (332-335).

Sannappa, B. and Manjunath, K.G. 2013. Fertility status of soils in the selected regions of the Western Ghats of Karnataka, India. Scholars Academic Journal of Bioscience. 1(5): 200-208.

Sharma, R.P., Singh, M. and Sharma, J.P. 2003. Correlation studies on micronutrients vis-à-vis soil properties in some soils of Nagaar district in semiarid region of Rajasthan. J. Indian Soc. Soil Sci., 51(4) : 522-527.

Singh, K.N., Raju, N.S., Subba Rao, A., Abhishek Rathore, Sanjay Srivastava, R.K., Samanta and Maji, A.K. 2005. Prescribing Optimum Doses of Nutrients for Target Yield Through Soil Fertility Maps in Andhra Pradesh. $J$. Ind. Soc. Agril. Statist. 59(2):131-140. 
Srikanth, K.S., Patil, P.L., Dasog, G.S. and Gali, S.K. 2007. Mapping of available major nutrients of a microwater -shed in northern dry zone of Karnataka. Karnataka J. Agric. Sci., 21(3):391-395.

Sudharani, Y., Jayasree, G. and Sesha Sai, M.V.R. 2013. Mapping of nutrient status of rice soils in Visakhapatnam district using GIS techniques Asian Journal of Soil Science, vol.-8: 325-329.

Subbiah, B.V. and Asija, G.L. 1956. A rapid procedure for estimation of available Nitrogen in soil. Current Science 25: 256-260.
Talele,P. E., Zende,G.K., Patil,Y.M. and Sonar,K.R.1992.Various 103 Forms of potassium in soils of Maharashtra occurring under different Agro-climatic Zone.J.potassium Res. 8 (2): 113-120.

Watanabe, F.S. and Olsen, S.R. 1965. Test of ascorbic acid methods for phosphorous in water and sodium bicarbonate extract of soil. Proc. Soil Sci. Am. 21: 677-678.

Williams and Steinbergs. 1959. Soil Sulphur fractions as chemical indices of available Sulphur in Australian soils. Australian Journal of Agriculture Research 10:340-35.

\section{How to cite this article:}

Ushasri, B. and Mukesh Kumar, C. 2019. GPS-GIS based Soil Fertility Maps of Bhudargad Tehsil of Kolhapur District (M.S.). Int.J.Curr.Microbiol.App.Sci. 8(09): 523-532. doi: https://doi.org/10.20546/ijcmas.2019.809.063 